\title{
The ability of Junior High School Science Teacher in Solving The Problems of Torque
}

\author{
Dios Sarkity ${ }^{* 1)}$, Putri Dwi Sundari ${ }^{2)}$ \\ 1) Biology Education, Raja Ali Haji Maritime University \\ ${ }^{2)}$ Physics Education, State University of Padang \\ e-mail: ${ }^{* 1)}$ diossarkity@umrah.ac.id \\ putridwisundari@fmipa.unp.ac.id
}

\begin{abstract}
Understanding the concept is an important aspect of solving various physics problems. Understanding the concept will help in understanding the problems, determining problem-solving strategies, and using mathematics appropriately as a problem-solving tool. Lack of conceptual understanding results in the tendency to solve problems by relying solely on formulas without knowing the proper use of formulas according to the underlying concepts of the problem. Various problems related to rotational motion can be explained through the concept of torque. To solve the problem of torque, understanding the concept of torque and mastering the concept of vectors are needed to find solutions to the problems. Many of the science teachers have a background in physics education. Science teachers who are a bachelor of physics education should master various physics concepts even though the material is not taught at the junior high school level. Therefore, the authors conducted research to determine the ability of science teachers with an education background in physics education in solving the problems of torque. The study involved 10 science teachers who teach in 10 different schools. This research was a descriptive study with data collection techniques in the form of a questionnaire using an essay question to test the science teacher's ability in solving the problems of torque. The results showed that most of the participants could not solve the problem of torque due to a lack of understanding of the concept in determining the torque generated by forces with various positions.
\end{abstract}

Keywords: the ability of science teachers, problem solving, torque. 


\title{
Kemampuan Guru IPA SMP dalam Menyelesaikan Masalah Momen Gaya
}

\author{
Dios Sarkity $^{* 1)}$, Putri Dwi Sundari ${ }^{2)}$ \\ ${ }^{1)}$ Pendidikan Biologi, Universitas Maritim Raja Ali Haji \\ ${ }^{2)}$ Pendidikan Fisika, Universitas Negeri Padang
}

\begin{abstract}
Abstrak
Pemahaman konsep menjadi aspek penting dalam menyelesaikan berbagai masalah fisika. Pemahaman konsep akan membantu dalam memahami masalah, menentukan strategi pemecahan masalah serta menggunakan matematika secara tepat sebagai alat pemecahan masalah. Kurangnya pemahaman konsep mengakibatkan kecenderungan memecahkan masalah dengan hanya mengandalkan rumus tanpa mengetahui penggunaan rumus secara tepat sesuai konsep yang mendasari masalah. Berbagai permasalahan yang berhubungan dengan gerak rotasi dapat dijelaskan melalui konsep momen gaya. Untuk menyelesaikan masalah momen gaya, pemahaman konsep momen gaya serta penguasaan konsep vektor sangat dibutuhkan untuk menemukan solusi masalah. Banyak diantara guru IPA memiliki latar belakang pendidikan fisika. Guru IPA yang merupakan sarjana pendidikan fisika seharusnya menguasai berbagai konsep fisika meskipun materi tersebut tidak diajarkan pada tingkat SMP. Oleh karena itu penulis melakukan penelitian untuk mengetahui kemampuan guru IPA dengan latar belakang pendidikan fisika dalam menyelesaikan masalah momen gaya. Penelitian melibatkan 10 Guru IPA yang mengajar di 10 sekolah yang berbeda. Penelitian ini merupakan penelitian deskriptif dengan teknik pengumpulan data berupa kuesioner menggunakan suatu soal essay untuk menguji kemampuan guru IPA dalam menyelesaikan masalah momen gaya. Hasil penelitian menunjukkan bahwa sebagian besar partisipan tidak bisa menyelesaikan masalah momen gaya dikarenakan kurangnya pemahaman konsep dalam menentukan momen gaya yang dihasilkan oleh gaya dengan berbagai posisi gaya.
\end{abstract}

Kata kunci: kemampuan guru IPA, pemecahan masalah, momen gaya.

\section{Pendahuluan}

Berbagai permasalahan dalam kehidupan sehari-hari dapat diselesaikan dengan konsep fisika. Pemahaman konsep yang baik menjadi aspek penting dalam menyelesaikan berbagai masalah fisika (Ding et al., 2011; Docktor \& Mestre, 2014; Nova et al., 2020). Pemahaman konsep yang baik akan membantu dalam dalam memahami permasalahan secara baik, menentukan strategi yang tepat untuk memecahkan masalah, dan menggunakan persamaan matematika secara tepat untuk menemukan solusi masalah (Docktor et al., 2015; Reif \& Heller, 2009). Pemahaman konsep yang baik akan membantu dalam mengidentifikasi aspek penting dari masalah (Morphew et al., 2015) kemudian membangun suatu pemodelan awal untuk menyelesaikan masalah (Cheng \& Brown, 2010).

Pemecahan masalah yang tidak didukung dengan pemahaman konsep yang baik akan menimbulkan berbagai permasalahan. Kurangnya pemahaman konsep menyebabkan adanya kecenderungan dalam memecahkan masalah secara kuantitatif dengan hanya mengandalkan rumus yang ada (Ibrahim \& Rebello, 2012; Walsh et al., 2007) tanpa mengasosiasikan antara rumus dan persamaan matematika yang digunakan dengan konsep fisika yang mendasari masalah (Hu \& Rebello, 2013; Nguyen \& Rebello, 2011). Kurangnya pemahaman konsep juga menyebabkan kesulitan dalam menyelesai kan permasalahan-permasalahan dengan konsep yang sama tetapi disajikan secara berbeda (De Cock, 2012; Lin \& Singh, 2013; Meltzer, 2005).

Berbagai permasalahan yang berhubungan dengan gerak rotasi dapat diselesaikan melalui konsep dinamika rotasi. Hasil penelitian menunjukkan masih terdapat banyak kesulitan dalam memahami konsep dinamika rotasi yang salah satunya adalah konsep momen gaya (Carvalho \& Sampaio, 2005; Duman et al., 2015; Rimoldini \& Singh, 2005; Syahrul \& Setyarsih, 2015). Kesulitan dalam memahami konsep momen gaya menyebabkan ketidakmampuan dalam menganalisis momen gaya yang dihasilkan oleh gaya dengan berbagai posisi 
terhadap poros (Rahmawati et al., 2016; Sarkity et al., 2016). Sebaliknya. Pemahaman konsep momen gaya yang baik akan membantu dalam mengindentifikasi momen gaya yang dihasilkan oleh gaya dengan berbagai posisi terhadap poros (Sarkity et al., 2018).

Momen gaya merupakan besaran vektor. Momen gaya ( $\boldsymbol{\tau})$ merupakan vektor yang dihasilkan oleh perkalian cross antara vektor lengan gaya $(\boldsymbol{r})$ dan vektor gaya $(\boldsymbol{F})$ menurut persamaan $\boldsymbol{\tau}=\boldsymbol{r} \times \boldsymbol{F}$. Pemahaman konsep yang baik mengenai vektor sangat diperlukan untuk menyelesaikan masalah mekanika seperti masalah momen gaya (Barniol \& Zavala, 2014a; Mikula \& Heckler, 2017). Hasil penelitian menunjukkan bahwa kesulitan dalam pemecahan masalah fisika salah satunya dikarenakan oleh kesulitan dalam memahami konsep vektor (Campos et al., 2020; Pepper et al., 2012). Kesulitan-kesulitan dalam memahami konsep vektor diantaranya adalah kesulitan dalam menentukan besar dan arah vektor (Barniol \& Zavala, 2014a; Knight, 1995; Nguyen \& Meltzer, 2003), kesulitan dalam mengoperasikan vektor seperti penjumlahan dan pengurangan serta perkalian vektor secara cross dan dot (Barniol \& Zavala, 2014b; Deprez et al., 2019; Heckler \& Scaife, 2015). Untuk perkalian vektor secara cross, masih terdapat kesulitan dalam menggunakan kaidah tangan kanan untuk menentukan arah vektor hasil perkalian cross (Kustusch, 2016).

IPA merupakan salah satu mata pelajaran wajib yang diajarkan di Sekolah Menengah Pertama (SMP). Seorang guru IPA harus menguasai dasar keilmuan fisika, biologi, dan kimia. Keberhasilan pembelajaran yang dilakukan oleh seorang guru tidak hanya didukung oleh kemampuan pedagogik guru (Yerushalmi \& Eylon, 2013), tetapi juga pengetahuan guru mengenai disiplin ilmu yang diajarkan (Etkina et al., 2018). Posisi guru IPA di beberapa sekolah masih diisi oleh guru-guru dengan latar belakang pendidikan fisika. Guru IPA dengan latar belakang pendidikan fisika seharusnya memiliki pemahaman konsep yang baik mengenai berbagai konsep fisika meskipun materi tersebut tidak diajarkan di tingkat SMP. Dengan modal pemahaman konsep tersebut, guru IPA dengan latar belakang pendidikan fisika juga bisa menyelesaikan berbagai masalah fisika pada tingkat SMA. Oleh karena itu, peneliti melakukan penelitian untuk mengetahui kemampuan guru IPA SMP dengan latar belakang pendidikan fisika dalam menyelesaikan masalah fisika pada topik momen gaya yang diajarkan pada tingkat SMA.

\section{Metode Penelitian}

Penelitian ini dilakukan pada Februari 2020. Penelitian ini melibatkan 10 orang guru IPA Sekolah Menengah Pertama (SMP) yang mengajar di SMP di Provinsi Riau dan Provinsi Kepulauan Riau. Guru IPA yang terlibat dalam penelitian ini merupakan guru IPA yang memiliki latar belakang pendidikan yaitu pendidikan fisika. Penelitian ini merupakan penelitian deskriptif dengan pengumpulan data dilakukan menggunakan kuesioner dalam bentuk soal essay. Soal essay yang digunakan merupakan soal untuk menguji kemampuan guru IPA SMP dalam menyelesaikan masalah momen gaya yang merupakan materi fisika SMA. Jawaban yang diberikan oleh guru IPA dianalisis secara kuantitatif deskriptif dengan melihat jawaban yang diberikan guru IPA secara keseluruhan, untuk mengetahui kemampuan guru IPA SMP dalam menyelesaikan masalah momen gaya.

Setelah menganalisis jawaban yang diberikan secara keseluruhan, analisis data dilanjutkan dengan mendeskripsikan kemampuan guru IPA dalam menyelesaikan masalah momen gaya berdasarkan jawaban yang diberikan. Deskripsi yang diberikan berisi tentang kemampuan guru IPA dalam menyelesaikan masalah momen gaya ditinjau dari kemampuan guru IPA dalam menentukan besar dan arah momen gaya yang dihasilkan oleh berbagai gaya dengan berbagai posisi terhadap poros benda, arah rotasi yang diakibatkan oleh momen gaya, serta resultan momen gaya yang dihasilkan.

\section{Hasil dan Pembahasan}

Kemampuan guru IPA dalam menyelesaikan masalah momen gaya dilakukan dengan menggunakan suatu soal essay seperti yang ditunjukkan pada Gambar 1. Gambar 1 menunjukkan bahwa terdapat 4 buah gaya dengan posisi yang berbeda terhadap terhadap poros benda bekerja untuk membuat benda 
berotasi. Momen gaya yang dihasilkan oleh setiap benda berbeda-beda bergantung pada posisi vektor gaya terhadap poros serta besar vektor gaya dan vektor lengan gaya. Perbedaan posisi gaya terhadap poros serta perbedaan besar vektor gaya dan vektor lengan gaya ini akan mempengaruhi besar momen gaya yang dihasilkan, arah momen gaya serta arah rotasi yang dihasilkan.

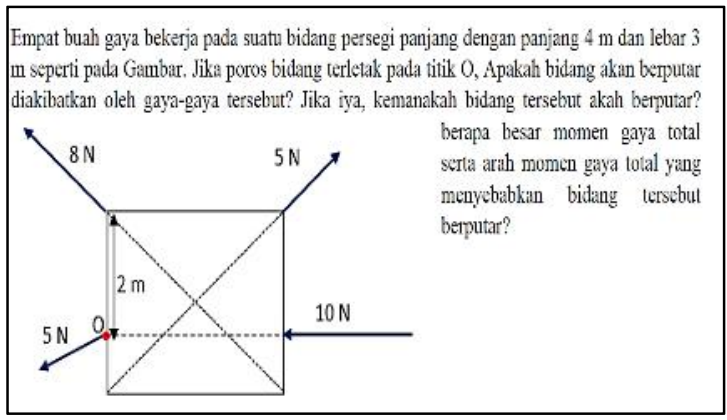

Gambar 1. Soal momen gaya.

Berikut akan dijabarkan dalam beberapa bagian tentang kemampuan guru IPA dalam menentukan momen gaya yang dihasilkan oleh setiap gaya dengan berbagai posisi terhadap poros benda serta arah momen gaya dan arah rotasi yang diakibatkan oleh momen gaya.

\section{Gaya yang bekerja pada poros bidang}

Gambar 1 menunjukkan bahwa terdapat satu gaya yang bekerja pada poros bidang di titik $\mathrm{O}$ yaitu gaya sebesar $5 \mathrm{~N}$. Momen gaya yang dihasilkan oleh gaya yang bekerja pada titik poros sama dengan nol. Pada konsep ini, semua guru mampu menganalisis momen gaya secara tepat. Semua guru mampu menyatakan momen gaya yang dihasilkan oleh gaya yang bekerja pada poros bidang sama dengan nol.

Contoh jawaban hasil analisis momen gaya yang dihasilkan oleh gaya yang bekerja pada poros bidang ditunjukkan oleh jawaban Guru 1 pada Gambar 2. Pada Gambar 2 dapat dilihat bahwa Guru 2 menyatakan bahwa besar vektor lengan gaya (R) sama dengan nol, karena bekerja pada titik putar benda sehingga ketika dimasukkan ke dalam rumus momen gaya maka momen gaya yang dihasilkan akan bernilai nol.

\section{Vektor gaya yang sejajar dengan vektor lengan gaya}

Dapat dilihat pada soal bahwa ada satu gaya yang posisinya segaris dengan titik poros $\mathrm{O}$ yaitu gaya sebesar $10 \mathrm{~N}$. Jika digambarkan, maka didapatkan bahwa vektor lengan gaya yang dihasilkan sejajar dengan vektor gaya yang bekerja pada bidang seperti yang ditunjukkan pada Gambar 3. Untuk gaya yang bekerja sejajar yang dihasilkan juga sama dengan nol sesuai dengan prinsip perkalian vektor secara cross

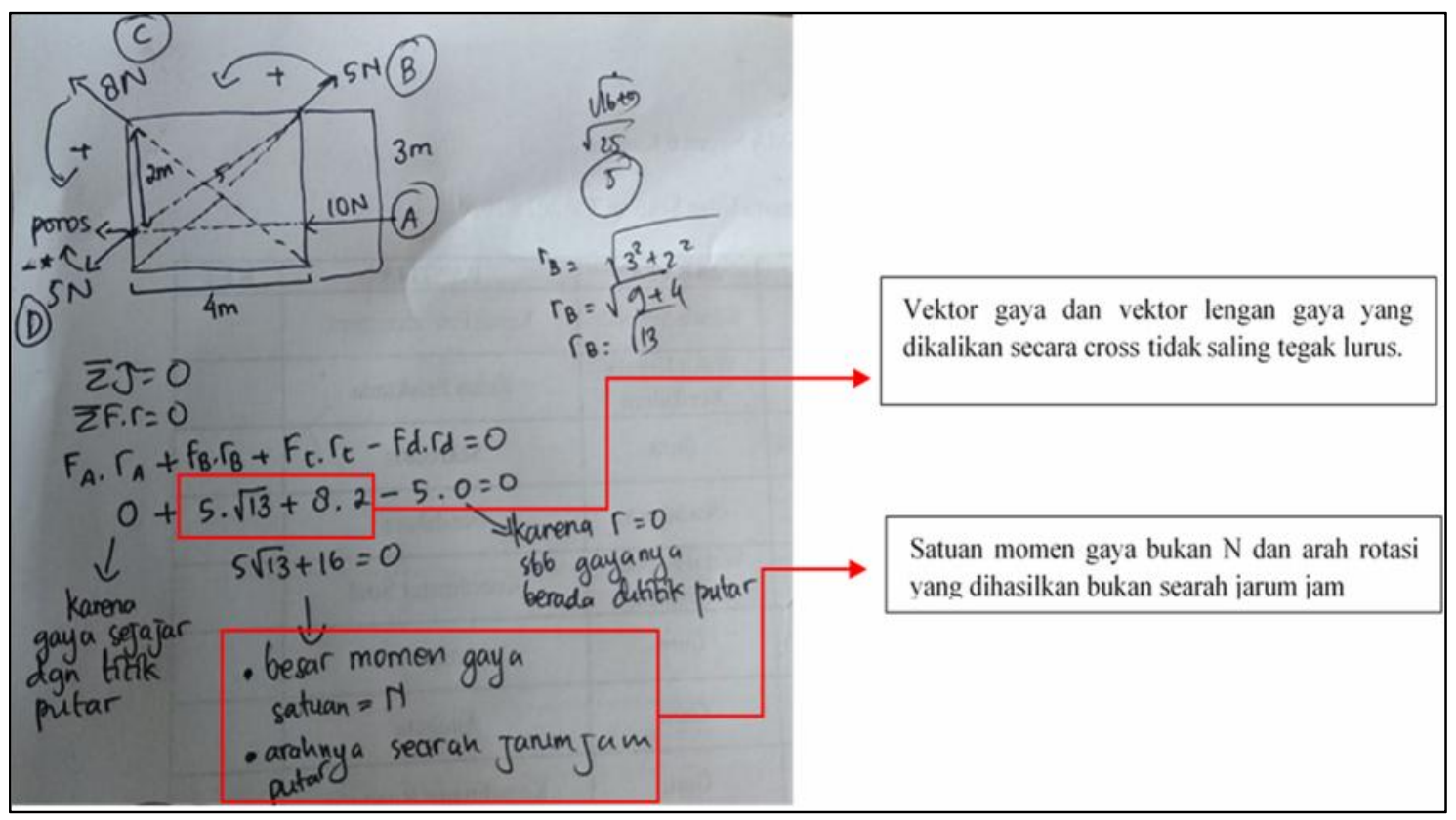

Gambar 2. Jawaban Guru 1 dalam menyelesaikan masalah momen gaya. 


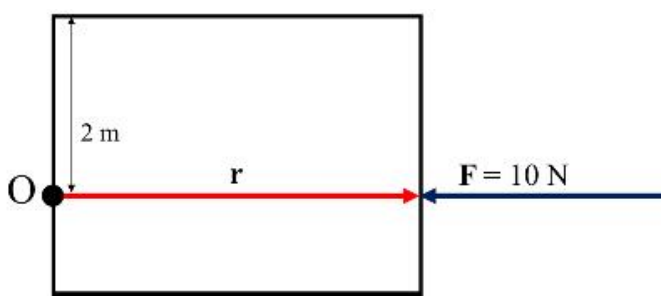

Gambar 3. Penggambaran vektor lengan gaya untuk gaya yang segaris dengan titik poros.

terhadap vektor lengan gaya, maka momen gaya menurut persamaan $\tau=\boldsymbol{r} \times \boldsymbol{F}$. Momen gaya hanya dihasilkan oleh vektor lengan gaya yang tegak lurus terhadap vektor gaya.

Sebanyak 8 guru pada bagian ini yang mampu menyatakan bahwa momen gaya yang dihasilkan oleh vektor gaya yang sejajar dengan vektor lengan gaya sama dengan nol. Selain dari 8 guru tersebut, terdapat 2 guru yang melakukan kesalahan. Contoh kesalahan yang dilakukan ditunjukkan oleh jawaban Guru 5 pada Gambar 4. Pada jawaban Guru 5 dapat dilihat bahwa guru tersebut langsung saja memasukkan besar dari vektor gaya dan vektor lengan gaya ke dalam rumus tanpa menganalisis terlebih dahulu posisi dari kedua vektor. Hal ini menunjukkan bahwa Guru 5 belum memahami bahwa momen gaya dihasilkan oleh vektor lengan gaya yang saling tegak lurus terhadap vektor gaya.

\section{Vektor gaya dan vektor lengan gaya yang membentuk sudut terhadap bidang vertikal dan bidang horizontal.}

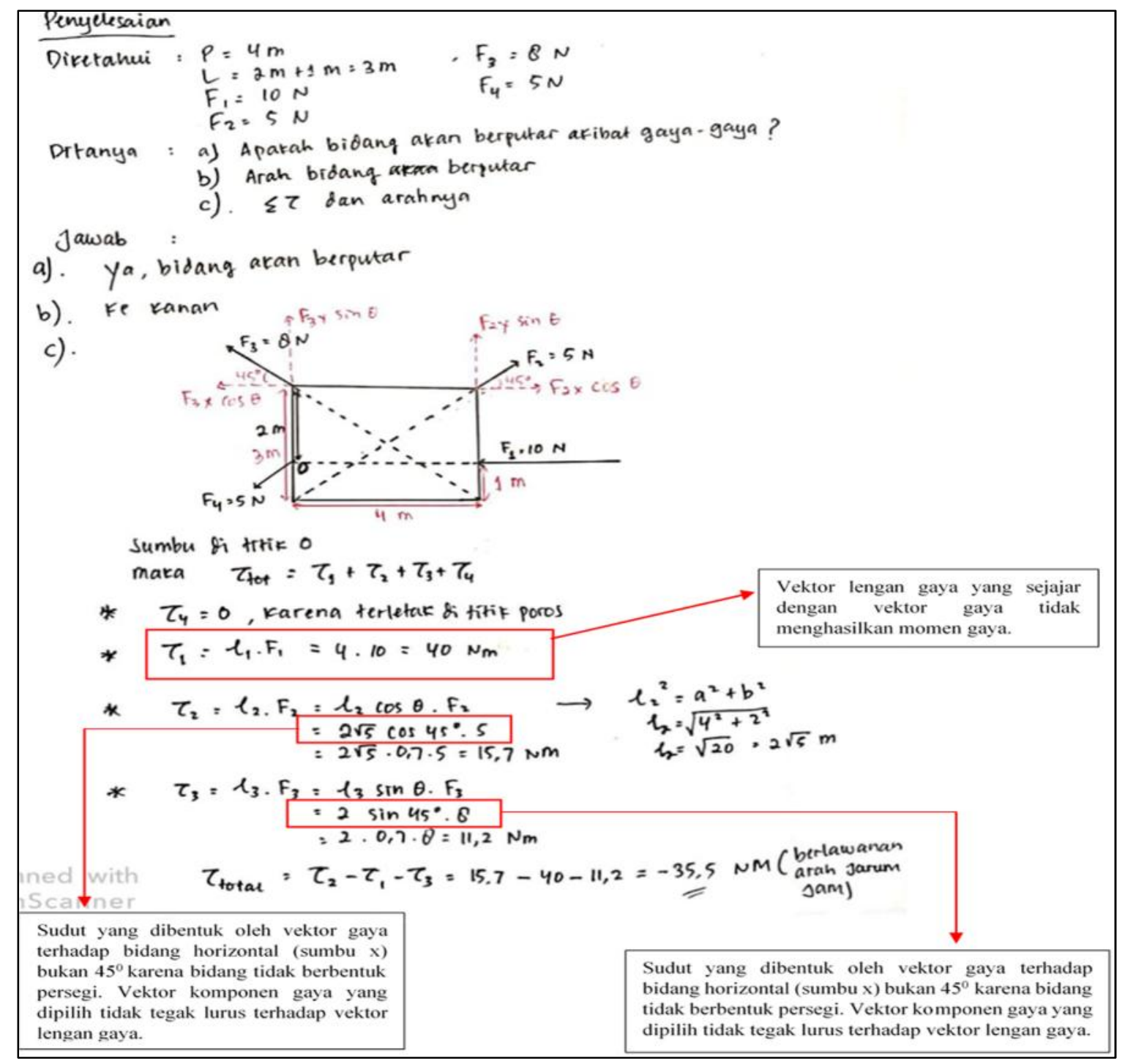

Gambar 4. Jawaban Guru 5 dalam menyelesaikan masalah momen gaya. 
Soal pada Gambar 5 menunjukkan bahwa terdapat satu gaya yang posisinya segaris dengan diagonal bidang persegi panjang yang besarnya 5 N. Jika digambarkan, vektor lengan gaya untuk

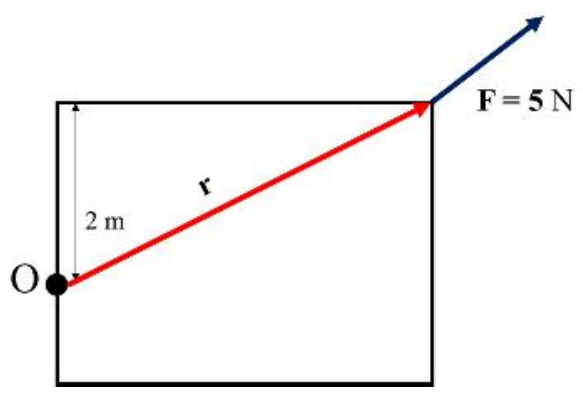

Gambar 5. Vektor gaya dan vektor lengan gaya yang sama-sama membentuk sudut tertentu pada bidang vertikal dan bidang horizontal.

gaya ini adalah seperti yang ditunjukkan pada Gambar 5. Gambar 5 dapat dilihat bahwa baik vektor gaya maupun vektor lengan gaya samasama membentuk sudut tertentu terhadap bidang vertikal maupun bidang horizontal. Untuk mendapatkan momen gaya yang dihasilkan oleh gaya ini maka baik vektor gaya maupun vektor lengan gaya harus diuraikan vektor komponennya baik pada arah vertikal maupun pada arah horizontal.

Terkait bagian ini, hanya satu guru yang mampu memberikan jawaban secara tepat yaitu Guru 10 yang jawabannya ditunjukkan pada Gambar 6. Pada jawaban Guru 10 dapat dilihat bahwa Guru 10 mampu menentukan momen gaya yang dihasilkan oleh gaya ini dengan menguraikan perhitungan momen gaya menjadi dua bagian yaitu (1) momen gaya hasil perkalian cross antara vektor komponen lengan gaya pada arah horizontal dengan vektor komponen gaya pada arah vertikal dan (2) momen gaya hasil perkalian cross antara vektor komponen lengan gaya pada arah vertikal dengan vektor komponen gaya pada arah horizontal. Berdasarkan jawaban

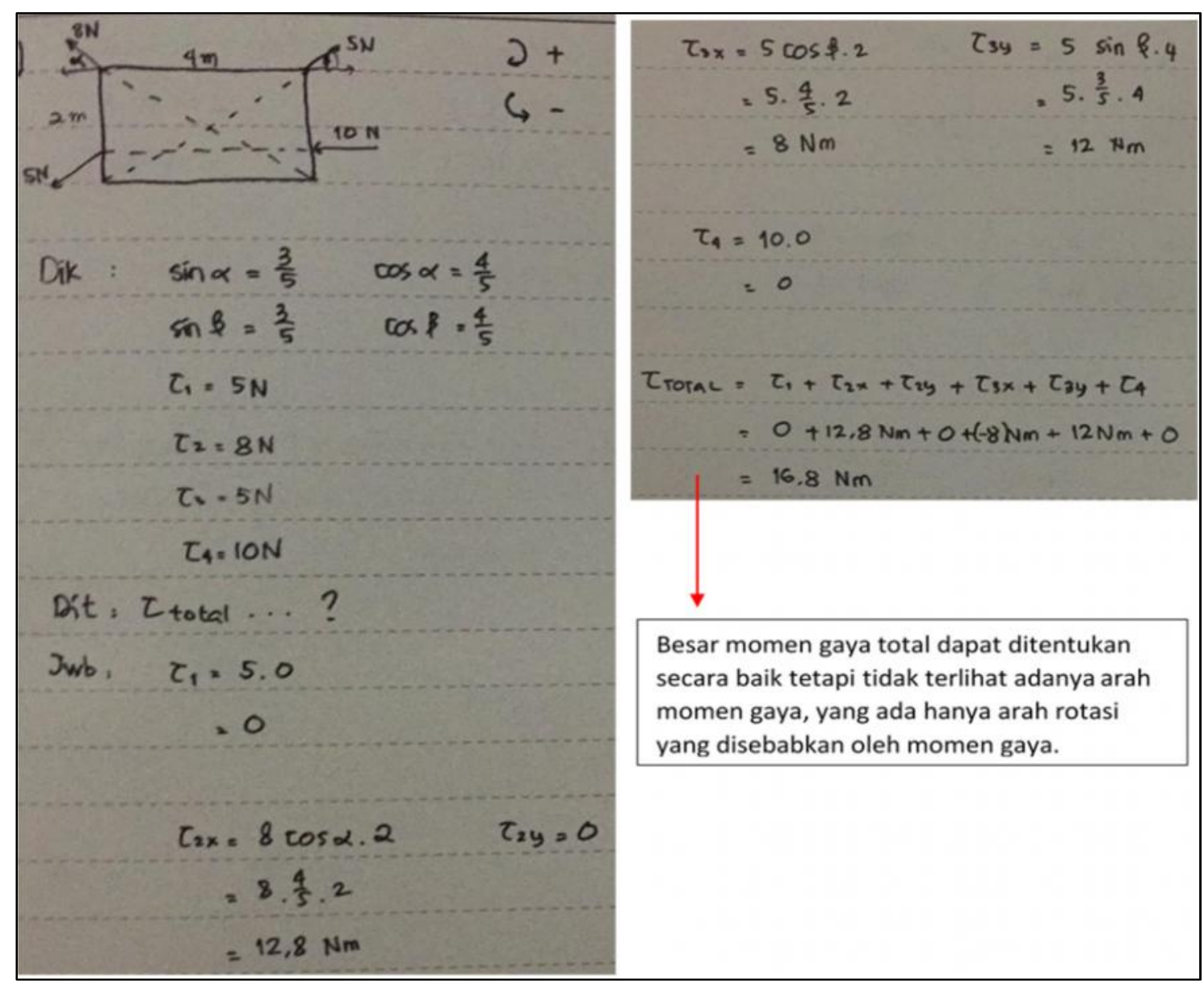

Gambar 6. Jawaban Guru 10 dalam menyelesaikan masalah momen gaya. 


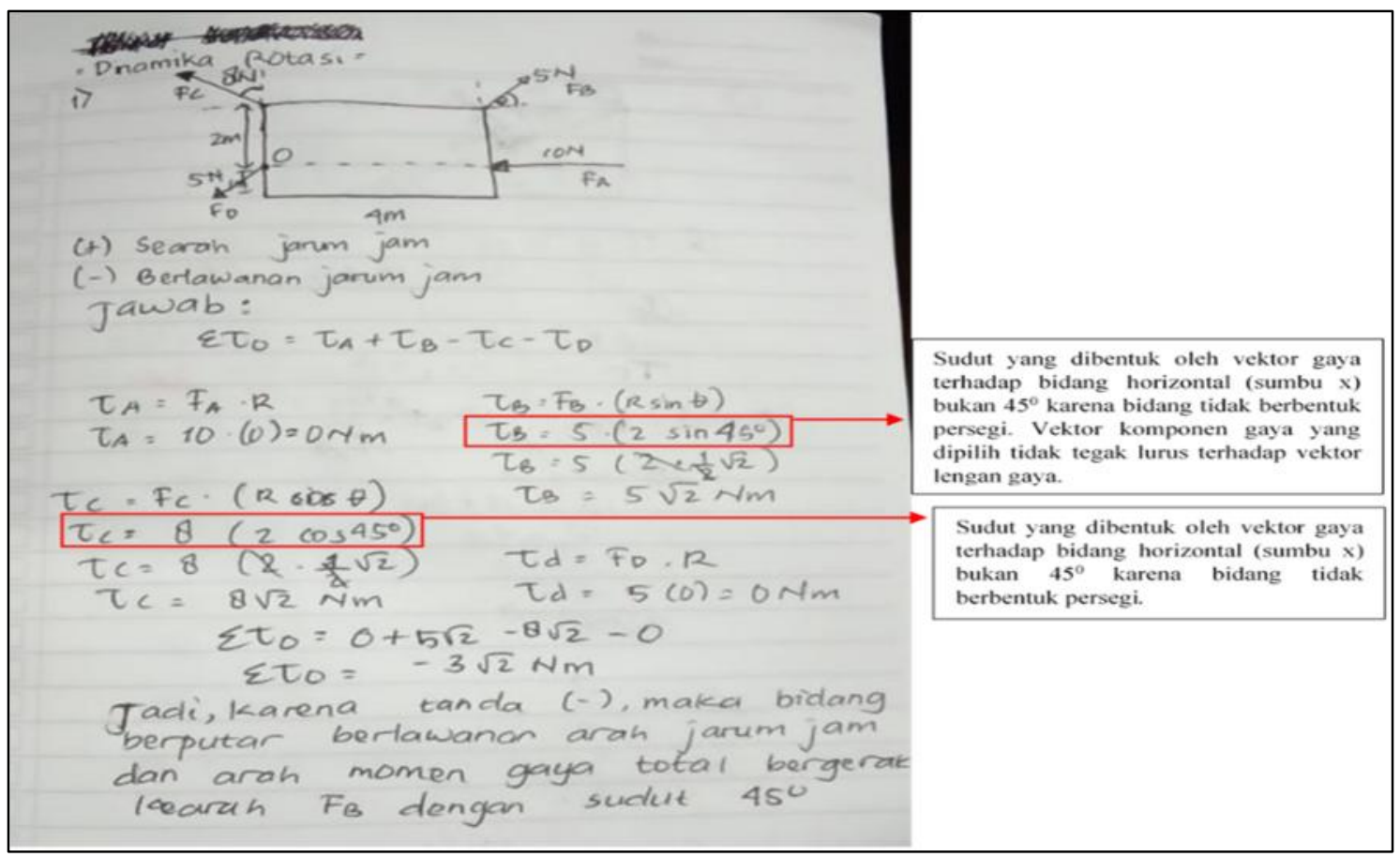

Gambar 7. Jawaban Guru 3 dalam menyelesaikan masalah momen gaya.

Guru 10 juga menunjukkan bahwa Guru ini mampu secara tepat menentukan nilai sin dan cos dari sudut yang terbentuk antara vektor gaya terhadap bidang horizontal.

Penentuan momen gaya oleh gaya ini, terdapat beberapa kesalahan yang dilakukan oleh beberapa guru. Diantaranya adalah kesalahan dalam menentukan besar sudut yang terbentuk antara vektor gaya dan bidang horizontal. Bidang yang ditunjukkan pada soal berbentuk persegi panjang, bukan persegi. Karena vektor gaya satu garis lurus dengan diagonal persegi panjang, maka sudut yang dibentuk oleh gaya terhadap bidang horizontal bukanlah $45^{\circ}$. Dari analisis jawaban yang dilakukan, didapatkan 5 orang guru yang salah dalam menganalisis besar sudut antara gaya terhadap bidang horizontal yang salah satunya dilakukan oleh Guru 5 seperti yang ditunjukkan pada Gambar 4. Contoh lain dari guru yang salah dalam menentukan besar sudut ini adalah Guru 3 yang jawabannya ditunjukkan pada Gambar 7.

Kesalahan lain yang ditemukan dalam menentukan momen gaya yang dihasilkan oleh gaya ini adalah adanya beberapa guru yang menentukan momen gaya dengan langsung

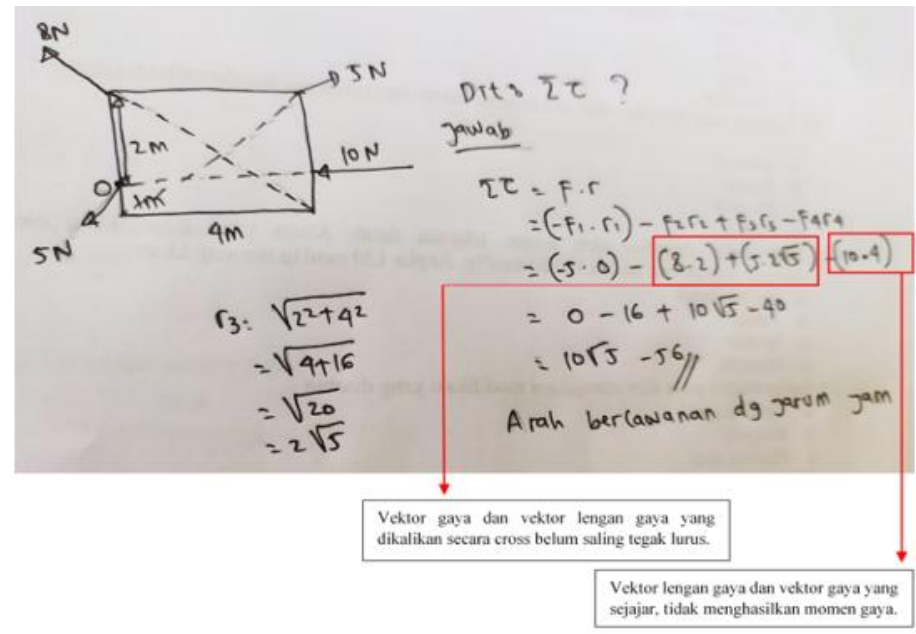

Gambar 8. Jawaban Guru 5 dalam menyelesaikan masalah momen gaya. 
memasukkan besar vektor lengan gaya dan besar vektor gaya ke dalam rumus tanpa terlebih dahulu menganalisis posisi kedua vektor. Kesalahan ini menunjukkan bahwa guru tersebut tidak memahami bahwa momen gaya dihasilkan oleh vektor lengan gaya dan vektor gaya yang posisinya saling tegak lurus. Contoh jawaban yang menunjukkan kesalahan ini adalah jawaban Guru 1 yang ditunjukkan pada Gambar 2. Selain itu, kesalahan ini juga dapat diilihat melalui jawaban Guru 5 seperti yang ditunjukkan pada Gambar 8.

\section{Vektor gaya yang membentuk sudut terhadap bidang vertikal dan bidang horizontal.}

Gaya pada bagian 4 adalah gaya sebesar $8 \mathrm{~N}$ yang secara karakteristik sama seperti gaya yang dibahas pada bagian 3 yaitu gaya yang membentuk sudut tertentu terhadap bidang horizontal maupun vertikal. Perbedaannya adalah vektor lengan gaya pada bagian 4 tepat berada pada bidang horizontal seperti yang ditunjukkan pada Gambar 9. Untuk mendapatkan vektorvektor yang saling tegak lurus, cukup menguraikan vektor komponen dari salah satu vektor, vektor komponen gaya saja atau vektor komponen lengan gaya saja.

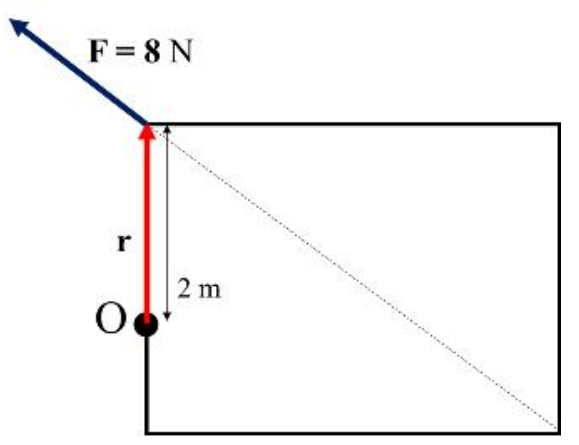

Gambar 9. Penggambaran vektor lengan gaya pada gaya yang membentuk sudut tertentu terhadap bidang horizontal dan vertikal.

Terkait vektor gaya ini, terdapat dua orang guru yang secara tepat menentukan momen gaya yang dihasilkan oleh gaya ini yaitu Guru 10 yang jawabannya ditunjukkan pada Gambar 6 dan juga Guru 8 yang jawabannya ditunjukkan pada Gambar 10. Pada Gambar 10 dapat dilihat bahwa Guru 8 secara tepat menguraikan vektor komponen gaya pada arah horizontal maupun vertikal. Guru 8 juga memahami cara menentukan besar nilai sin dan cos dari sudut yang terbentuk antara vektor gaya terhadap bidang horizontal. Selain itu, Guru 8 juga memahami bahwa momen gaya dihasilkan oleh vektor lengan gaya dan vektor gaya yang saling tegak lurus sehingga Guru 8 memilih vektor komponen gaya pada arah horizontal yang menghasilkan momen gaya pada kasus ini.

Terdapat beberapa kesalahan yang dilakukan oleh Guru-Guru lainnya selain dari Guru 8 dan Guru 10. Kesalahan-kesalahan yang dilakukan hampir sama dengan kesalahan yang dilakukan dalam menentukan momen gaya yang dihasilkan oleh gaya pada bagian 3. Kesalahan pertama yaitu kesalahan dalam menganalisis besar sudut yang terbentuk antara gaya dengan bidang horizontal seperti yang ditunjukkan oleh jawaban Guru 5 pada Gambar 4 dan jawaban Guru 3 pada Gambar 7. Melalui kedua gambar tersebut dapat dilihat bahwa baik Guru 5 maupun Guru 3 menyatakan bahwa besar sudut yang terbentuk antara vektor gaya terhadap bidang horizontal adalah $45^{\circ}$ padahal bidang yang ditunjukkan pada soal bukan berbentuk persegi tetapi persegi panjang. Karena vektor gaya segaris dengan diagonal bidang persegi panjang, maka besar sudut yang terbentuk antara vektor gaya dengan bidang horizontal bukan $45^{\circ}$.

Selain kesalahan dalam menganalisis besar sudut yang terbentuk antara vektor gaya terhadap bidang horizontal, kesalahan lain yang ditemukan adalah kesalahan dalam memahami konsep momen gaya. Momen gaya dihasilkan oleh vektor gaya dan vektor lengan gaya yang saling tegak lurus, tetapi berdasarkan analisis jawaban dapat dilihat bahwa beberapa guru menentukan momen gaya tanpa menganalisis terlebih dahulu posisi gaya terhadap lengan gaya. Jawaban Guru 1 yang ditunjukkan oleh Gambar 2 menunjukkan bahwa Guru 1 hanya mengandalkan rumus momen gaya dalam menentukan momen gaya, kemudian memasukkan besar vektor gaya dan vektor lengan gaya ke dalam rumus tanpa menganalisis terlebih dahulu posisi antara kedua vektor. Pada jawaban Guru 5 yang ditunjukkan oleh gambar 4, terjadi kesalahan yang berulang dimana Guru 5 sebanyak dua kali menyatakan bahwa momen gaya dihasilkan oleh vektor gaya yang sejajar dengan vektor lengan gaya. Untuk gaya pada bagian 4 ini, Guru 5 sudah menguraikan vektor komponen gaya baik pada arah vertikal maupun pada arah horizontal, tetapi pada saat menggunakan rumus momen gaya, Guru 5 memilih vektor komponen pada arah 


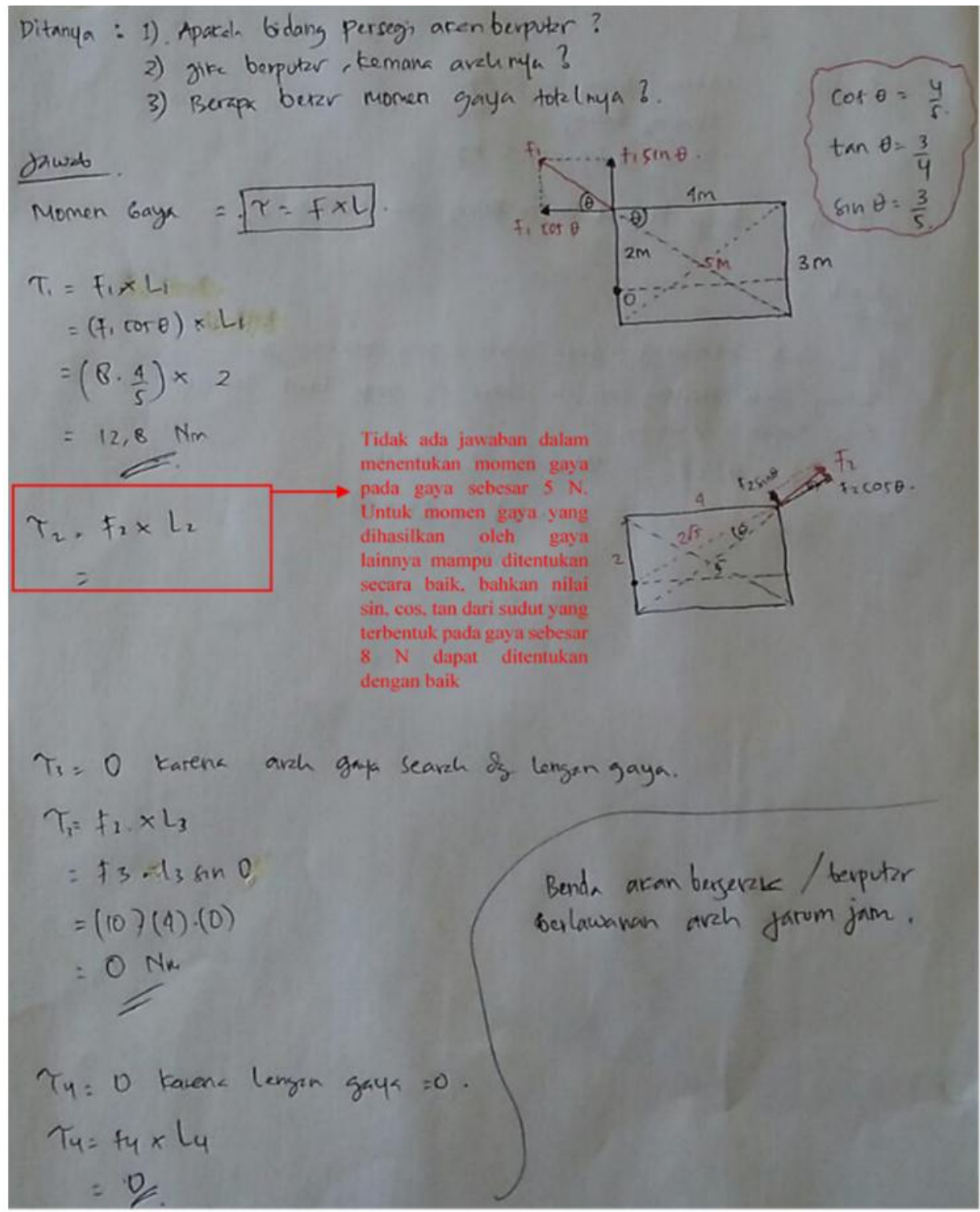

Gambar 10. Jawaban Guru 8 dalam menyelesaikan masalah momen gaya.

vertikal yang sejajar dengan lengan gaya yang menghasilkan momen gaya. Kesalahan ini konsisten dengan kesalahan yang dilakukan oleh Guru 5 pada saat menentukan momen gaya pada gaya bagian 2 .

Kesalahan yang ditunjukkan pada jawaban guru dalam menganalisis momen gaya seperti yang dijelaskan pada bagian 2,3 dan 4 menunjukkan bahwa masih adanya kesulitan dalam memahami konsep momen gaya sejalan dengan hasil penelitian Carvalho \& Sampaio E Sousa (2005), Duman et al. (2015), Rimoldini \& Singh (2005) dan Syahrul \& Setyarsih (2015). Kesulitan ini meliputi kesulitan dalam menganalisis momen gaya yang dihasilkan oleh berbagai gaya khususnya gaya-gaya yang membentuk sudut tertentu terhadap bidang vertikal dan horizontal (Rahmawati et al., 2016; Sarkity et al., 2016). Berdasarkan jawaban yang diberikan juga masih ditemukan adanya guru yang menyatakan bahwa vektor gaya yang sejajar dengan vektor lengan gaya menghasilkan momen gaya yang tidak nol, hal ini menunjukkan guru tersebut tidak mampu memaknai notasi persamaan momen gaya yang menggunakan prinsip perkalian vektor secara cross. Ketidakmampuan guru menguraikan vektor komponen dalam arah vertikal dan horizontal serta ketidakmampuan memaknai perkalian vektor secara cross menunjukkan adanya kesulitan dalam memahami konsep vektor (Barniol \& Zavala, 2014a; Knight, 1995; 
Nguyen \& Meltzer, 2003), khususnya dalam pengoperasian vektor (Barniol \& Zavala, 2014b; Deprez et al., 2019; Heckler \& Scaife, 2015;). Kesulitan ini menyebabkan guru hanya mengandalkan rumus yang ada dalam menentukan momen gaya (Ibrahim \& Rebello, 2012; Walsh et al., 2007) tanpa mengetahui penggunaan rumus secara tepat sesuai konsep (Hu \& Rebello, 2013; Nguyen \& Rebello, 2011).

\section{Arah momen gaya dan arah rotasi.}

Momen gaya $(\boldsymbol{\tau})$ merupakan besaran vektor hasil perkalian cross antara vektor lengan gaya $(\boldsymbol{r})$ dan vektor gaya $(\boldsymbol{F})$ menurut persamaan $\boldsymbol{\tau}=$ $\boldsymbol{r} \times \boldsymbol{F}$. Arah vektor momen gaya saling tegak lurus satu sama lain terhadap arah vektor lengan gaya dan arah vektor gaya. Berdasarkan jawaban yang diberikan oleh 10 Guru, tidak ada satupun guru yang menyatakan arah vektor momen gaya. Ke-10 guru menganggap bahwa arah rotasi yang diakibatkan oleh momen gaya merupakan arah vektor momen gaya.

Untuk menyatakan arah rotasi yang diakibatkan momen gaya, hampir semua guru sudah dapat menyatakannya secara baik. Tetapi masih terdapat satu guru yang salah dalam menentukan arah rotasi yang diakibatkan oleh momen gaya. Kesalahan tersebut dapat dilihat dari jawaban Guru 1 pada Gambar 2. Kesalahan tersebut secara jelas dapat dilihat pada jawaban Guru 1 dalam menentukan momen gaya pada gaya bagian 4, dimana Guru 1 menyatakan bahwa arah rotasi yang dihasilkan oleh momen gaya searah jarum jam, seharusnya arah rotasi yang diakibatkan oleh momen gaya adalah berlawanan arah jarum jam sesuai dengan arah vektor gaya dan arah vektor lengan gaya.

Hasil ini menunjukkan bahwa masih terdapat guru yang tidak mengetahui bahwa momen gaya merupakan besaran vektor yang memiliki besar dan arah. Arah vektor momen gaya ditentukan melalui perkalian cross antara vektor lengan gaya dan vektor gaya. Hasil ini menunjukkan bahwa masih terdapat kesulitan dalam memahami operasi vektor khususnya memaknai perkalian vektor secara cross (Barniol \& Zavala, 2014b; Deprez et al., 2019; Heckler \& Scaife, 2015). Untuk arah vektor momen gaya dapat ditentukan dengan kaidah tangan kanan (Kustusch, 2016) dengan melihat arah vektor lengan gaya dan arah vektor gaya.

\section{Resultan momen gaya}

Resultan momen gaya ditentukan dengan cara menjumlahkan vektor-vektor momen gaya. Vektor momen gaya dijumlahkan dengan memperhatikan arah setiap vektor momen gaya. Pada bagian ini, hanya Guru 10 saja yang menghasilkan besar resultan momen gaya secara tepat. Untuk guru guru yang lain, karena terdapat kesalahan dalam menentukan momen gaya yang dihasilkan oleh setiap gaya, maka besar resultan momen gaya yang dihasilkan pun juga salah. Hal ini menunjukkan pentingnya pemahaman konsep untuk mengindentifikasi aspek penting dari masalah (Morphew et al., 2015) yang dalam hal ini adalah identifikasi posisi vektor gaya terhadap vektor lengan gaya untuk menentukan ada tidaknya momen gaya yang dihasilkan.

Meskipun Guru 10 mampu menghasilkan besar resultan momen gaya secara tepat tetapi solusi masalah belum sempurna karena Guru 10 tidak mampu menyatakan arah vektor momen gaya secara tepat. Guru 10 hanya menyatakan arah rotasi yang diakibatkan oleh resultan momen gaya total. Seperti yang dijelaskan pada bagian 5 , bahwa arah vektor momen gaya tidak sama dengan arah rotasi yang diakibatkan oleh momen gaya.

\section{Kesimpulan}

Berdasarkan hasil uji kemampuan Guru IPA SMP dalam menyelesaikan masalah momen gaya, ditemukan bahwa masih terdapat kesulitan pada Guru IPA SMP dalam menyelesaikan masalah momen gaya, meskipun latar belakang pendidikan Guru IPA tersebut adalah pendidikan fisika. Kesulitan-kesulitan dalam menyelesaikan masalah momen gaya meliputi kesulitan dalam menentukan posisi vektor gaya yang menghasilkan momen gaya, kesulitan dalam menguraikan vektor komponen gaya ataupun vektor komponen lengan gaya yang membentuk sudut tertentu terhadap bidang vertikal dan horizontal, serta kesulitan dalam menganalisis besar sudut yang terbentuk antara vektor gaya dan vektor lengan gaya terhadap bidang vertikal dan horizontal secara geometri. Selain itu, kesulitan dalam menyelesaikan momen gaya ini juga disebabkan oleh kesulitan dalam memahami operasi vektor khususnya perkalian vektor secara cross sehingga tidak ada satupun guru yang menyatakan arah vektor momen gaya secara tepat. 
Sebagai guru, kemampuan harus senantiasa ditingkatkan salah satunya adalah pemahaman konsep. Pemahaman konsep merupakan aspek penting untuk memecahkan berbagai masalah. Agar dapat menciptakan suatu pembelajaran yang dapat meningkatkan kemampuan pemecahan masalah, guru harus terlebih dahulu memperkuat pemahaman konsep siswa. Oleh karena itu, guru harus memiliki pemahaman konsep yang baik mengenai disiplin ilmu yang diajarkan untuk dapat memperkuat pemahaman konsep siswa dan melatihkan kemampuan pemecahan masalah.

\section{Daftar Pustaka}

Barniol, P., \& Zavala, G. (2014a). Force, Velocity, and Work: The Effects of Different Contexts on Students' Understanding of Vector Concepts Using Isomorphic Problems. Physical Review Special Topics-Physics Education Research, 10(2), 1-15. https://doi.org/ 10.1103/PhysRev STPER.10.020115

Barniol, P., \& Zavala, G. (2014b). Test of Understanding of Vectors: A reliable Multiple-choice Vector Concept Test. Physical Review Special Topics - Physics Education Research, 10(1), 1-14. https://doi.org/10.1103/PhysRevSTPER.1 0.010121

Campos, E., Zavala, G., Zuza, K., \& Guisasola, J. (2020). Students' Understanding of the Concept of the Electric Field through Conversions of Multiple Representations. Physical Review Physics Education Research, 16(1), 10135. https://doi.org/ 10.1103/PHYSREVPHYSEDUCRES.16. 010135

Carvalho, P. S., \& Sampaio E Sousa, A. (2005). Rotation in Secondary School: Teaching the Effects of Frictional Force. Physics Education, 40(3), 257-265. https://doi. org/10.1088/0031-9120/40/3/007

Cheng, M. F., \& Brown, D. E. (2010). Conceptual Resources in Self-developed Explanatory Models: The Importance of Integrating Conscious and Intuitive Knowledge. International Journal of Science Education, 32(17), 2367-2392. https://doi.org/10.1080/095006909035757 55
De Cock, M. (2012). Representation Use and Strategy Choice in Physics Problem Solving. Physical Review Special Topics Physics Education Research, 8(2), 1-15. https://doi.org/10.1103/PhysRevSTPER.8. 020117

Deprez, T., Gijsen, S. E., Deprez, J., \& De Cock, M. (2019). Investigating Student Understanding of Cross Products in a Mathematical and Two Electromagnetism Contexts. Physical Review Physics Education Research, 15(2), 20132. https://doi.org/10.1103/PhysRevPhysEduc Res.15.020132

Ding, L., Reay, N., Lee, A., \& Bao, L. (2011). Exploring the role of conceptual scaffolding in solving synthesis problems. 020109, 1-11. https://doi.org/10.1103/ PhysRevSTPER.7.020109

Docktor, J. L., \& Mestre, J. P. (2014). Synthesis of Discipline-based Education Research in Physics. Physical Review Special Topics Physics Education Research, 10(2), 1-58. https://doi.org/10.1103/PhysRevSTPER.1 0.020119

Docktor, J. L., Strand, N. E., Mestre, J. P., \& Ross, B. H. (2015). Conceptual Problemsolving in High School Physics. Physical Review Special Topics - Physics Education Research, 11(2), 1-13. https://doi.org/10. 1103/PhysRevSTPER.11.020106

Duman, I., Demirci, N., \& Sekercioglu, A. (2015). University Students' Difficulties And Misconceptions on Rolling, Rotational Motion and Torque Concepts. International Journal on New Trends in Education and Their Implications, 6(1), 46-54.

Etkina, E., Gitomer, D., Iaconangelo, C., Phelps, G., Seeley, L., \& Vokos, S. (2018). Design of An Assessment to Probe Teachers' Content Knowledge For Teaching: An Example from Energy in High School Physics. Physical Review Physics Education Research, 14(1), 10127. https://doi.org/10.1103/ PhysRev PhysEducRes.14.010127

Heckler, A. F., \& Scaife, T. M. (2015). Adding and Subtracting Vectors: The Problem with the Arrow Representation. Physical Review Special Topics-Physics Education Research, 11(1), 1-17. https://doi.org/10. 1103/PhysRevSTPER.11.010101 
Hu, D., \& Rebello, N. S. (2013). Using Conceptual Blending to Describe how Students Use Mathematical Integrals in Physics. Physical Review Special Topics Physics Education Research, 9(2), 1-15. https://doi.org/10.1103/PhysRevSTPER.9. 020118

Ibrahim, B., \& Rebello, N. S. (2012). Representational Task Formats and Problem Solving Strategies in Kinematics and Work. Physical Review Special Topics - Physics Education Research, 8(1), 1-19. https://doi.org/10.1103/PhysRevSTPER.8. 010126

Knight, R. D. (1995). The Vector Knowledge of Beginning Physics Students. The Physics Teacher, 33(2), 74-77. https://doi.org/10. $1119 / 1.2344143$

Kustusch, M. B. (2016). Assessing the Impact of Representational and Contextual Problem Features on Student Use of Righthand Rules. Physical Review Physics Education Research, 12(1), 1-22. https://doi.org/10. 1103/PhysRevPhysEducRes.12.010102

Lin, S. Y., \& Singh, C. (2013). Using An Isomorphic Problem Pair to Learn Introductory Physics: Transferring from A Two-Step Problem to A Three-step Problem. Physical Review Special Topics Physics Education Research, 9(2), 11-19. https://doi.org/10.1103/PhysRevSTPER.9. 020114

Meltzer, D. E. (2005). Relation between Students' Problem-solving Performance and Representational Format. American Journal of Physics, 73(5), 463-478. https://doi.org/10.1119/1.1862636

Mikula, B. D., \& Heckler, A. F. (2017). Framework and Implementation for Improving Physics Essential Skills Via Computer-based Practice: Vector Math. Physical Review Physics Education Research, 13(1), 1-23. https://doi.org/10. 1103/PhysRevPhysEducRes.13.010122

Morphew, J. W., Mestre, J. P., Ross, B. H., \& Strand, N. E. (2015). Do Experts and Novices Direct Attention Differently in Examining Physics Diagrams? A Study of Change Detection Using the Flicker Technique. Physical Review Special Topics-Physics Education Research, 11(2), 1-6. https://doi.org/10.1103/ PhysRevSTPER.11.020104
Nguyen, D. H., \& Rebello, N. S. (2011). Students' Understanding and Application of the Area Under the Curve Concept in Physics Problems. Physical Review Special Topics-Physics Education Research, 7(1), 1-17. https://doi.org/ 10.1103/PhysRevSTPER.7.010112

Nguyen, N. L., \& Meltzer, D. E. (2003). Initial understanding of vector concepts among students in introductory physics courses. American Journal of Physics, 71(6), 630638. https://doi.org/10.1119/1.1571831

Nova, N. R., Fakhruddin, \& Yennita. (2020). Analysis Understanding of Concept in Sound Wave Materials and Light in Class XI Senior High School Students Tampan Pekanbaru. 8(1), 33-41.

Pepper, R. E., Chasteen, S. V., Pollock, S. J., \& Perkins, K. K. (2012). Observations on Student Difficulties with Mathematics In Upper-division Electricity and Magnetism. Physical Review Special Topics - Physics Education Research, 8(1), 1-15. https://doi.org/10.1103/PhysRevSTPER.8. 010111

Rahmawati, I., Sutopo, \& Zulaikah, S. (2016). Identifikasi Kesulitan Mahasiswa pada Materi Dinamika Rotasi. Prosiding Semnas Pendidikan IPA Pascasarjana UM, 1, 284-. (2016). Identifikasi Kesulitan Mahasiswa pada Materi Dinamika Rotasi. Prosiding Semnas Pendidikan IPA Pascasarjana UM, 1, 284-293.

Reif, F., \& Heller, J. I. (2009). Knowledge Structure and Problem Solving in Physics Knowledge Structure and Problem Solving in Physics. April 2013, 37-41.

Rimoldini, L. G., \& Singh, C. (2005). Student Understanding of Rotational and Rolling Motion Concepts. Physical Review Special Topics - Physics Education Research, 1(1). https://doi.org/10.1103/PhysRevSTPER.1. 010102

Sarkity, D., Yuliati, L., \& Hidayat, A. (2016). Kesulitan Siswa SMA dalam Memecahkan Masalah Kesetimbangan dan Dinamika Rotasi. In Prosiding Semnas Pendidikan IPA Pascasarjana UM: Vol. I (pp. 166173).

Sarkity, D., Yuliati, L., \& Hidayat, A. (2018). Kemampuan Siswa dalam Memecahkan Masalah Momen Gaya Melalui Pembelajaran Berbasis Masalah. Jurnal 
Pendidikan Teori Penelitian dan Pengembangan, 3(2), 195-199.

Syahrul, D. A., \& Setyarsih, W. (2015). Identifikasi Miskonsepsi dan Penyebab Miskonsepsi Siswa dengan Three-tier Diagnostic Test Pada Materi Dinamika Rotasi. Jurnal Inovasi Pendidikan Fisika (JIPF), 04(03), 67-70.

Walsh, L. N., Howard, R. G., \& Bowe, B. (2007). Phenomenographic Study of Students' Problem Solving Approaches in Physics. Physical Review Special Topics Physics Education Research, 3(2), 1-12.
https://doi.org/10.1103/PhysRevSTPER.3. 020108

Yerushalmi, E., \& Eylon, B. S. (2013). Supporting Teachers who Introduce Curricular Innovations into Their Classrooms: A Problem-solving Perspective. Physical Review Special Topics - Physics Education Research, 9(1), 1-23. https://doi.org/10.1103/PhysRev STPER.9.010121 